\title{
FAKTOR-FAKTOR YANG BERHUBUNGAN DENGAN MUTU PELAYANAN PRIMA DI RUANG RAWAT INAP KEBIDANAN RSIA ERIA BUNDA PEKANBARU
}

TAHUN 2019

Widya Juliarti, Wella Chelsy Dhea

STIKes Hang Tuah Pekanbaru

\begin{abstract}
Service Excellent is an effort that serves needs of others or which means helping and preparing what is needed by someone. with excellent or excellent serve is high and satisfying. The low quality of excellent service at the Eria Bunda Pekanbaru Hospital can be seen from the initial survey where the services provided were not as good as there are still non-functioning facilities, facilities that have not been updated and, nurses and midwives are less friendly to the patient's family. Which is the purpose of this paper is to find out "Factors Associated With Quality Of Service Excellent In The Room Hospitalization Obstetrics RSIA Eria Bunda Pekanbaru 2019". The method in this study is quantitative with a cross sectional design. The respondents were patients who is numbered 94 people. Thus sampling is done by simple random sampling. The analysis used is univariate and bivariate analysis with chi-square test, the measuring instruments used are questionnaires and data processing using SPSS or computerization. The results of the 4 variables found that the four variables relate to excellent service quality, namely the attitude with $p$ value $0.048<0.05$, with a $p$ value of $0.000<0.05$, appearance with $p$ value $0.023<0.05$, and responsibility with $p$ value $0.035<0.05$.
\end{abstract}

Keyword: Attitude,action, Performance, Responsible.

\begin{abstract}
ABSTRAK
Pelayanan prima (Service Excellent) merupakan usaha yang melayani kebutuhan orang lain atau yang berarti membantu dan menyiapkan apa yang diperlukan oleh seseorang.dengan arti prima atau excellent adalah bermutu tinggi dan memuaskan. Masih rendahnya mutu pelayanan prima di RSIA Eria Bunda Pekanbaru dapat dilihat dari survey awal dimana pelayanan yang diberikan belum baik seperti, masih adanya fasilitas yang tidak berfungsi, fasilitas yang belum diperbaharui dan, perawat dan bidan yang kurang ramah kepada keluarga pasien.Yang mana tujuan dari penelitian ini adalah untuk mengetahui 'Faktor-Faktor Yang Berhubungan Dengan Mutu Pelayanan Prima Di Ruang Rawat Inap Kebidanan RSIA Eria Bunda Pekanbaru Tahun 2019'. Metode dalam penelitian ini adalah kuantitatif dengandesain cross sectional. Respondennya adalah pasien yang berjumlah 94 orang.Dengan demikian pengambilan sampel secara simple random sampling atau acak sederhana. Analisis yang digunakan adalah analisis univariat dan bivariat dengan uji chi-square, alat ukur yang digunakan adalah kuesioner dan pengolahan data menggunakan komputerisasi. Hasil penelitian dari 4 variabel ditemukan keempat
\end{abstract}


variabel tersebut berhubungan dengan mutu pelayanan prima, yaitu sikap dengan $\mathrm{p}$ value $0,048<0,05$, tindakan dengan $\mathrm{p}$ value $0,000<0,05$, penampilan dengan $\mathrm{p}$ value $0,023<$ 0,05 , dan tanggung jawab dengan $\mathrm{p}$ value $0,035<0,05$.

\section{Kata Kunci $\quad$ : Sikap, Tindakan, Penampilan, dan Tanggung Jawab.}

\section{PENDAHULUAN}

Pelayanan prima merupakan pelayanan yang sangat baik dan melampaui harapan pelangan dan pelayanan yang memiliki ciri khas kualitas (quality nice) (Rahmayanty, 2010). Sedangkan Barata (2016), pelayanan prima yaitu terpenuhinya kebutuhan dan mewujudkan kepuasan dari pelanggan tersebut agar mereka royal kepada perusahaan serta menunjukan kepedulian terhadap pelanggan dengan memberikan layanan yang terbaik untuk memfasilitasi kemudahan pemenuhan kebutuhan. Menurut Purwoastuti, dkk (2015) Pelayanan prima di Rumah Sakit adalah pelayanan terbaik yang diberikan oleh karyawan RS unuk memenuhi/bahkan melampaui harapan pengguna masa lalu terhadap jasa atau produk yang pernah digunakan, informasi layanan yang diterima dari berbagai sumber atau janji-janji dan factor internal dari pengguna jasa yaitu dari pengguna jasa rumah sakit sendiri.

Berdasarkan penelitian Ulfa dkk (2016), dengan judul Faktor-Faktor Yang Berhubungan Dengan Pelayanan Petugas Pendaftaran Rawat Jalan Terhadap Pelayanan Primadi Rumah Sakit Umum Daerah Petal Bumi Provinsi Riau Tahun 2016, bahwa terdapat hubungan antara kemampuan petugas pelayanan pendaftaran rawat jalan dengan pelayanan prima di RSUD Petala Bumi Provinsi Riau dengan hasil uji chi square $p$ Value $=0,001$ lebih kecil dari $\alpha=$ 0,05 , selanjutnya terdapat hubungan antara penampilan petugas pelayanan pendaftaran rawat jalan dengan pelayanan prima di RSUD Petala Bumi Provinsi Riau dengan hasil uji chi square $p$ Value $=0,585$ lebih kecil dari $\alpha=0,05$, selanjutnya terdapat hubungan antara sikap petugas pelayanan pendaftaran rawat jalan dengan pelayanan prima di RSUD Petala Bumi Provinsi Riau dengan hasil uji chi square $p$ Value $=0,003$ lebih kecil dari $\alpha=0,05$, selanjutnya terdapat hubungan antara perhatian petugas pelayanan pendaftaran rawat jalan dengan pelayanan prima di RSUD Petala Bumi Provinsi Riau dengan hasil uji chi square $p$ Value $=0,001$ lebih kecil dari $\alpha=0,05$, selanjutnya terdapat hubungan antara tindakan petugas pelayanan pendaftaran rawat jalan dengan pelayanan prima di RSUD Petala Bumi Provinsi Riau dengan hasil uji chi square $p$ Value $=0,049$ lebih kecil dari $\alpha=0,05$, selanjutnya terdapat hubungan antara tanggung jawab petugas pelayanan pendaftaran rawat jalan dengan pelayanan prima di RSUD Petala Bumi 
Provinsi Riau dengan hasil uji chi square $p$

Value $=0,003$ lebih kecil dari $\alpha=0,05$

Rumah Sakit Ibu dan Anak Eria Bunda Pekanbaru adalah Rumah Sakit Khusus milik Swasta,berada di lokasi strategis Kecamatan Sukajadi Kelurahan Kampung Tengah, tepatnya di Jalan K.H.Ahmad Dahlan No.163 Sukajadi Pekanbaru Riau. Rumah Sakit Ibu dan Anak Eria Bunda Pekanbaru berdasarkan Kepmenkes RI No. HK.03.05/I/1715/11 menjadi RS Khusus Kelas C, pada 07 Juli 2011 dan akan menjalani Akreditasi untuk5 Pelayanan Dasar yang mempunyai kapasitas 88 tempat tidur.

Dari 88 TT yang dapat dirincikan sebagai berikut: 1 Ruangan Perawatan Bougenvile Ibu terdiri dari ruangan President Raflesia Ibu terdiri dari ruangan VIP 4 Kamar 4 TT, Klas 1:4 kamar 8 TT, Klas II : 2 Kamar 6 TT, Klas III : 4 Kamar 16 TT jadi total : 14 Kamar 34 TT. 3. Ruangan Raflesia Anak terdiri dari ruangan PS : 2 Kamar 2 TT . VIP ; 4 Kamar 4 TT. Klas 1:2 kamar 4 TT. Klas II; 2 kamar 6 TT. Klas III;2 Kamar 6 TT. Ruangan Kemoterapi : 1 kamar 2 TT Jadi Total : 13 Kamar 24 TT. ICU ibu : 1 TT . ICU Anak: 1 TT. NICU : 2 TT . PN $2: 5$ TT . PN 3:2 TT Ruangan Pemulihan : 4 TT Jadi Total : 15 TT. Sehingga total tempat tidur terdiri dari ; anak 24 TT, Reflesia Ibu 34 TT, Bougenvile; 15 TT, NICU,PIC,ICU,PN2 15 TT jadi total keseluruhan ada 88 TT.Jumlah tenaga kesehatan perawat di RSIA Eria Bunda Pekanbaru sebanyak 48 orang, sedangkan jumlah bidan di RSIA Eria Bunda Pekanbaru sebanyak 50 orang.

Cakupan layanan kesehatan yang diberikan oleh RSIA Eria Bunda Pekanbaru meliputi instalasi gawat darurat, poliklinik rawat jalan, instalasi farmasi, rawat inap, HCU, ICU, NICU, PICU, instalasi gizi, laboratorium dan penunjang medis lainnya. Dan dibawah ini merupakan data kunjungan pasien selama tiga tahun terakir di RSIA Eria Bunda Pekanbaru.

Jumlah kunjungan pasien rawat inap anak dan ibu selama 3 tahun terakhir di RSIA Eria Bunda Pekanabru dapat dilihat, dimana pada tahaun 2016 jumlah kunjungan pasien rawat inap 5075 orang, dan pada tahun 2017 jumlah kunjungan pasien rawat inap mengalami penurunan sebanyak 4925 orang, dengan perbandingan kunjungan pasien rawat inap tahun 2016 dan 2017 sebanyak 150 orang. Jumlah kunjungan pasien pada tahun 2018 juga mengalami penurunan jika dibandingkan dengan tahun 2017 yaitu sebanyak 210 orang dengan jumlah keseluruhan pengunjung 4715 orang. Selain data jumlah kunjungan rawat inap diperoleh data pasien rawat inap ibu di kebidanan RSIA Eria Bunda Pekanbaru tiga tahun terakhir.

\section{Tabel 1}


Jumlah Kunjungan Pasien Rawat Inap Kebidanan di RSIA Eria Bunda Pekanbaru Tiga Tahun Terakhir

\begin{tabular}{cccc}
\hline \multirow{2}{*}{$\begin{array}{c}\text { N } \\
\text { o }\end{array}$} & Jenis & \multicolumn{2}{c}{ Jumlah Kunjungan Pasien } \\
\cline { 3 - 4 } & Persalinan & $\mathbf{2 0 1 6}$ & $\mathbf{2 0 1 7}$ \\
\hline 1. & SC & 1808 & 1794 \\
\hline 2. & Normal & 2542 & 2707 \\
\hline & Total & 4350 & 4501 \\
\hline
\end{tabular}

Sumber : Data Rekam Medis RSIA Eria

Bunda

Dari data diatas jumlah kunjungan pasien Sc dan Normal di rawat inap kebidanan selama 3 tahun terakhir di RSIA Eria Bunda Pekanabru dapat dilihat, dimana pada tahaun 2016 jumlah kunjungan pasien rawat inap Sc dan Normal 4350 orang, dan pada tahun 2017 jumlah kunjungan pasien rawat inap Sc dan Normal mengalami kenaikan sebanyak 4501 orang, dengan perbandingan kunjungan pasien rawat inap tahun 2016 dan 2017 sebanyak 151 orang. Namun jumlah kunjungan pasien rawat inap SC dan Normal pada tahun 2018 mengalami penurunan jika dibandingkan dengan tahun 2017 yaitu sebanyak 66 orang dengan jumlah keseluruhan pengunjung 4344 orang.

Dari hasil survei awal, telah dilakukan wawancara non formal terhadap 10 pasien di rawat inap kebidanan RSIA Eria Bunda Pekanbaru, dari hasil wawancara 6 dari 10 pasien tersebut mengatakan mutu pelayanan prima belum sesuai dengan yang diharapkan pasien dan keluarga di ruang rawat inap kebidanan. Pasien mengatakan bahwa beberapa diantaranya adalah fasilitas yang masih tidak berfungsi seperti kran air yang macet, dan fasilitas yang sudah lama dan tidak diperbarui seperti closet yang sudah berkarat dan tempat tidur yang masih model lama. Pasien juga mengatakan bahwa ada beberapa perawat dan bidan yang kurang ramah, dan tidak mau senyum jika berapapasan dengan keluarga pasien. Sedangkan 4 pasien mengatakan pelayanan prima di rumah sakit sudah baik. Oleh karena itu peneliti tertarik untuk melakukan penelitian tentang "Faktor-Faktor Yang Berhubungan Dengan Mutu Pelayanan Prima Di Ruang Rawat Inap Kebidanan RSIA Eria Bunda Pekanbaru Tahun 2019”. Tujuan penelitian ini adalah diketahui faktor-faktor yang berhubungan dengan Mutu Pelayanan Prima di Ruang Rawat Inap Kebidanan RSIA Eria Bunda Tahun 2019

\section{METODE}

Penelitian ini merupakan penelitian Kuantitatif dengan menggunakan desain penelitian Cross Sectionaldilakukan di ruang rawat inap Rumah Sakit Ibu dan Anak Eria Bunda Pekanbaru pada Tahun 2019 dan waktu kegiatan penelitian akan dilakukan pada bulan Mei - Juni 2019. Populasi dari penelitian ini berjumlah 4344 orang yang didapatkan dari data kunjungan pasien rawat inap kebidanan di rumah sakit pada tahun 
2018. Sampel dalam penelitian ini adalah seluruh responden ibu-ibu melahirkan yang telah di rawat inap kebidanan. Teknik sampling yang digunakan adalah Simple Random Sampling yaitu sampel dari populasi dilakukan secara acak tanpa melihat strata yang ada dalam populasi itu. Cara ini dilakukan apabila anggota populasi nya homogen (Sugiyono, 2017).

\section{HASIL}

Tabel 2

Karakteristik Responden

\begin{tabular}{cccc}
\hline N & Karakter & Frekuensi & $(\%)$ \\
o & Responden & & \\
\hline
\end{tabular}

\begin{tabular}{llcc}
\hline 1. & Umur & & \\
& 20-29 tahun & 50 & 53,2 \\
& 30-39 tahun & 36 & 38,3 \\
& 40-49 tahun & 8 & 8,5 \\
\hline 2. & Pendidikan & & \\
& SLTA & 11 & 11,7 \\
& DIII & 44 & 46,8 \\
SI & 39 & 41,5 \\
\hline
\end{tabular}

Berdasarkan tabel 6 diketahui sebagian besar responden berumur 30-39 tahun berjumlah 36 orang $(38,3 \%)$. Dan pada tingkat pendidikan sebagian besar responden memiliki pendidikan DIII dengan jumlah 44 orang $(46,8 \%)$.

a. Analisis Univariat

Tabel 7

Distribusi Frekuensi Faktor-Faktor Yang

Berhubungan Dengan Mutu Pelayanan

Prima

\begin{tabular}{lcc}
\hline \multicolumn{1}{c}{$\begin{array}{c}\text { Variabel } \\
\text { uji }\end{array}$} & $\begin{array}{c}\text { Frekue } \\
\text { nsi }\end{array}$ & $\begin{array}{c}\text { Persentas } \\
\mathrm{e}(\%)\end{array}$ \\
\hline $\begin{array}{l}\text { Pelayanan Prima } \\
\text { 1. Buruk }\end{array}$ & 47 & 50,0 \\
2. Baik & 47 & 50,0 \\
\hline $\begin{array}{l}\text { Sikap } \\
\text { 1. Buruk }\end{array}$ & 73 & 77,7 \\
2. Baik & 21 & 22,2 \\
\hline$\quad$ Tindakan & & \\
1. Buruk & 69 & 73,4 \\
2. Baik & 25 & 26,6 \\
\hline$\quad$ Penampilan & & \\
1. Buruk & 74 & 78,7 \\
2. Baik & 20 & 21,3 \\
\hline Tanggung Jawab & & \\
1. Tidak tanggung & & \\
jawab & & 90,4 \\
2. Tanggung jawab & 85 & 9,6 \\
$\quad$ Jumlah & 94 & 100.0 \\
\hline
\end{tabular}

\section{b. Analisis Bivariat}

Tabel 3

Hubungan Sikap, Tindakan, Penampilan, dan Tanggung Jawab Perawat dan Bidan denganMutu Pelayanan Prima

\begin{tabular}{|c|c|c|c|c|c|c|c|c|c|}
\hline \multirow{3}{*}{ No } & \multirow{3}{*}{$\begin{array}{c}\text { Variabel } \\
\text { Uji }\end{array}$} & \multicolumn{6}{|c|}{ Pelayanan Prima } & \multirow{3}{*}{$\begin{array}{c}\mathrm{P} \\
\text { value }\end{array}$} & \multirow{3}{*}{ POR 95\% CI } \\
\hline & & \multicolumn{2}{|c|}{ Buruk } & \multicolumn{2}{|c|}{ Baik } & \multicolumn{2}{|c|}{ Total } & & \\
\hline & & $\mathbf{N}$ & $\%$ & $\mathbf{N}$ & $\%$ & n & $\%$ & & \\
\hline 1 & Sikap & & & & & & & & \\
\hline
\end{tabular}




\begin{tabular}{|c|c|c|c|c|c|c|c|c|c|}
\hline & Buruk & 41 & 56,2 & 32 & 43,8 & 73 & 100 & \multirow{3}{*}{0,048} & \multirow[t]{3}{*}{$3,203(1,117-9,186)$} \\
\hline & Baik & 6 & 28,6 & 15 & 71,4 & 21 & 100 & & \\
\hline & Jumlah & 47 & 50,0 & 47 & 50,0 & 94 & 100 & & \\
\hline \multirow[t]{4}{*}{2} & Tindakan & & & & & & & & \\
\hline & Buruk & 43 & 62,3 & 26 & 37,7 & 69 & 100 & \multirow[t]{3}{*}{0,001} & \multirow[t]{3}{*}{$8,683(2,682-28,113)$} \\
\hline & Baik & 4 & 16,0 & 21 & 84,0 & 25 & 100 & & \\
\hline & Jumlah & 47 & 50,0 & 47 & 50,0 & 94 & 100 & & \\
\hline \multirow[t]{4}{*}{3} & $\begin{array}{c}\text { Penampila } \\
\mathrm{n}\end{array}$ & & & & & & & & \\
\hline & Baik & 42 & 56,8 & 32 & 43,2 & 74 & 100 & \multirow[t]{3}{*}{0,023} & \multirow[t]{3}{*}{$3,938(1,295-11,968)$} \\
\hline & Buruk & 5 & 25,0 & 15 & 75,0 & 20 & 100 & & \\
\hline & Jumlah & 47 & 50,0 & 47 & 50,0 & 94 & 100 & & \\
\hline \multirow[t]{3}{*}{4} & $\begin{array}{c}\text { Tanggung } \\
\text { Jawab }\end{array}$ & & & & & & & & \\
\hline & $\begin{array}{c}\text { Tidak } \\
\text { Tanggung } \\
\text { Jawab }\end{array}$ & 46 & 54,1 & 39 & 45,9 & 85 & 100 & \multirow[t]{2}{*}{0,035} & \multirow[t]{2}{*}{$9,436(1,130-78,783)$} \\
\hline & $\begin{array}{c}\text { Tanggung } \\
\text { Jawab }\end{array}$ & 1 & 11,1 & 8 & 88,9 & 9 & 100 & & \\
\hline & Jumlah & 47 & 50,0 & 47 & 50,0 & 94 & 100 & & \\
\hline
\end{tabular}

nilai $\mathrm{P}$ value $=0,048<\mathrm{a}_{0,05}$, maka ha ditolak dan ho diterima, dapat disimpulkan bahwa ada hubungan antara sikap perawat dan

Tabel 3 menunjukkan hubungan antara sikap perawat dan bidan dengan mutu pelayanan prima di ruang rawat inap kebidanan bahwa responden yang menyatakan pelayanan perawat dan bidan buruk dengan sikap perawat dan bidan yang buruk berjumlah 41 orang $(56,2 \%)$ serta dengan sikap perawat dan bidan yang baik berjumlah 6 orang $(28,6 \%)$, sedangkan responden yang menyatakan pelayanan perawat dan bidan baik dengan sikap perawat dan bidan yang buruk berjumlah 32 orang $(43,8 \%)$ serta sikap perawat dan bidan yang baik berjumlah 15 orang $(71,4 \%)$. Hasil uji statistik menggunakan Chi square diperoleh bidan dengan pelayanan prima. Dari hasil analisis diperoleh $\mathrm{POR}=3,203>1$. Artinya responden yang menyatakan sikap perawat dan bidan yang buruk berisiko 3,2 kali dengan pelayanan prima dibandingkan responden yang menyatakan sikap perawat dan bidan yang baik.

Hubungan antara tindakan perawat dan bidan dengan mutu pelayanan prima di ruang rawat inap kebidanan terdapat bahwa responden yang menyatakan pelayanan perawat dan bidan buruk dengan tindakan perawat dan bidan yang buruk berjumlah 43 orang $(62,3 \%)$ serta dengan tindakan perawat dan bidan yang baik berjumlah 4 orang 
$(16,0 \%)$, sedangkan responden menyatakan pelayanan perawat dan bidan baik dengan tindakan perawat dan bidan yang buruk berjumlah 26 orang $(37,7 \%)$ serta dengan tindakan perawat dan bidan yang baik berjumlah 21 orang (84,0\%). Hasil uji statistik menggunakan Chi square diperoleh nilai $\mathrm{P}$ value $=0,001<\mathrm{a}_{0,05}$, maka ha ditolak dan ho diterima, dapat disimpulkan bahwa ada hubungan antara tindakan dengan pelayanan prima. Dari hasil analisis diperoleh $\mathrm{POR}=8,683>1$. Artinya responden yang menyatakan tindakan perawat dan bidan yang buruk berisiko 8,6 kali dengan pelayanan prima dibandingkan responden yang menyatakan tindakan perawat dan bidan yang baik.

Hubungan antara penampilan perawat dan bidan dengan mutu pelayanan prima di ruang rawat inap kebidanan terdapat bahwa responden yang menyatakan pelayanan perawat dan bidan buruk dengan penampilan perawat dan bidan yang buruk berjumlah 42 orang $(56,8 \%)$ serta dengan penampilan perawat dan bidan yang baik berjumlah 5 orang (25,0\%), sedangkan responden menyatakan pelayanan perawat dan bidan baik dengan penampilan perawat dan bidan yang buruk berjumlah 32 orang $(43,2 \%)$ serta dengan penampilan perawat dan bidan yang baik berjumlah 15 orang $(75,0 \%)$.

Hasil uji statistik menggunakan Chi square diperoleh nilai $\mathrm{P}$ value $=0,023<\mathrm{a}_{0,05}$, maka ha ditolak dan ho diterima, dapat disimpulkan bahwa ada hubungan antara tampilan dengan pelayanan prima. Dari hasil analisis diperoleh $\mathrm{POR}=3,938>1$. Artinya responden menyatakan penampilan perawat dan bidan yang buruk berisiko 3,9 dengan pelayanan prima dibandingkan responden yang menyatakan penampilan perawat dan bidan yang baik.

Hubungan antara tanggung jawab perawat dan bidan dengan mutu pelayanan prima di ruang rawat inap kebidanan terdapat bahwa responden menyatakan pelayanan perawat dan bidan buruk dengan perawat dan bidan yang tidak bertanggung jawab berjumlah 46 orang $(54,1 \%)$ serta perawat dan bidan yang bertanggung jawab berjumlah 1 orang $(11,1 \%)$, sedangkan responden menyatakan pelayanan perawat dan bidan baik dengan perawat dan bidan yang bertanggung jawab berjumlah 39 orang $(45,9 \%)$ serta perawat dan bidan yang baik, bertanggung jawab berjumlah 8 orang (88,9\%). Hasil uji statistik menggunakan Chi square diperoleh nilai $\mathrm{P}$ value $=0,035<\mathrm{a}_{0,05}$, maka ha ditolak dan ho diterima, dapat disimpulkan bahwa ada hubungan antara tanggung jawab dengan pelayanan prima. Dari hasil analisis diperoleh $\mathrm{POR}=9,436>1$. Artinya responden yang menyatakan perawat dan bidan tidak bertanggung jawab berisiko 9,4 kali dengan pelayanan prima 
dibandingkan responden yang menyatakan tanggung jawab perawat dan bidan yang baik.

\section{PEMBAHASAN}

\section{Hubungan Sikap Perawat dan Bidan} Dengan Mutu Pelayanan Prima

.Hasil perhitungan Chi Square ditemukan ada hubungan antara sikap perawat dan bidan dengan mutu pelayanan prima di rumah sakit, yaitu dengan nilai Chi Square sebesar 3.924 dan signifikansi ( $p$-value) sebesar 0,048 $(\mathrm{p}<0,05)$.

Hasil penelitian ini sejalan dengan penelitian yang dilakukan oleh Nugrahaningsih (2016), tentang hubungan sikap perawat dengan kepuasan pasien dalam pelayanan keperawatan di Bangsal Pavilliun RSUD Salatiga. Hal ini menunjunkkan bahwa terdapat hubungan sikap perawat dengan kepuasan pasien dalam pelayanan keperawatan di Bangsal Pavilliun RSUD Salatiga (nilai $\mathrm{p}$-value $=0,000<0,05$ ), dan kekuatan yang terjadi pada kedua variabel tersebut kuat $(0,60-0,799)$ dengan arah positif.temuan fakta hasil penelitian ini memberikan gambaran bahwa sikap perawat akan berdampak pada timbulnya kepuasan keperawatan di Bangsal Pavilliun RSUD Salatiga. Adanya sikap perawat yang dinilai buruk oleh sebagian pasien tersebut menujukkan jika perawat belum memberikan pelayanan secara optimal, serta mampu mempertanggung jawabkan segala bentuk pelayanannya.

Hasil observasi pada faktor sikap yang diakukan oleh peneliti selama pengambilan data berlangsung, masih adanya perawat dan bidan yang kurang ramah atau senyum terhadap pasien maupun keluarga pasien.Hasil penelitian lainnya yang diteliti oleh Mony (2014), terdapat tidak ada hubungan antara sikap caring perawat dengan kepuasan pasien di ruang rawat inap kelas III di RS PKU Muhammadiyah Yogyakarta. Hal ini disebabkan karena perawat yang ada di bangsal kelas III RS PKU Muhammadiyah Yogyakarta menunjukkan sikap peduli dengan apa yang dirasakan pasien, selalu sedia dalam melayani kebutuhan pasien ketika membutuhkan bantuan dan membuat pasien merasa nyaman dan tentunya mereka diberi penilaian baik kepada perawat. Teori yang dikemukakan oleh Dwidiyanti dalam Mony (2014), bahwa bersikap caring kepada klien dan berkerjasama dengan klien dari berbagai lingkungan merupakan esensi perawatan dan sebagai suatu proses yang berorientasi pada tujuan membantu orang lain bertumbuh dan mengaktualisalikan diri. 
Sikap menurut Barata (2016) adalah perilaku atau perangai yang harus di tonjolkan ketika menghadapi pelangan, seperti berpikiran positif dan menghargai orang lain.sikap berkaitan dengan suatu kondisi yang ada di dalam diri seseorang maka sikap dapat pula diartikan sebagai alur pengekspresian perasaan (mood) dari seseorang kepada pihak lain. Jika sikap metal yang dimiliki seseorang positif maka kemungkinan besar ia berada pada posisi pemenang (the winner), sebaliknya jika sikap mental yang dimiliki seseorang negative maka kemungkinan besar ia aksn berada pada posisi yang kalsh (the loser) Daryanto dalam Ulfa, dkk (2016) sikap mencerminkan perilaku atau gerak gerik yang terlihat pada diri seseorang ketika ia menghadapi suatu situasi tertentu atau ketika ia berhadapan dengan orang lain.

Berdasarkan hasil penelitian dan teori yang relevan maka peneliti mendapatkan bahwa sikap perawat dan bidan baik buruknya tergantung dari pelayanan yang diterima oleh pasien. Sebagian responden menyatakan bahwa sikap perawat dan bidan buruk. Dari hasil kuesioner, responden banyak yang memilih tidak setuju pada "Ekspresi wajah perawat dan bidan dalam memberikan pelayanan baik", "Respon perawat dan bidan dalam mengatasi keluhan pasien sudah tepat" hal ini akan berakibat negatif bagi pandangan pasien terhadap profesionalisme perawat dan bidan dalam melakukan pelayanan kepada pasien. Berdasarkan hal tersebut diharapkan perawat dapat mengatasi keluhan pasien sesuai dengan yang diharapkan pasien.

\section{Hubungan Tindakan Perawat dan} Bidan Dengan Mutu Pelayanan Prima

Hubungan tindakan perawat dan bidan dengan mutu pelayanan prima dalam rumah sakit terlihat dari hasil tabel distribusi yang menunjukkan bahwa peningkatan tindakan perawat dan bidan kearah yang lebih baik akan diikuti oleh peningkatan mutu pelayanan prima dalam pelayanan di rumah sakit. Hasil perhitungan Chi Square ditemukan ada hubungan antara tindakan perawat dan bidan dengan mutu pelayanan prima di rumah sakit, yaitu dengan nilai $C h i$ Square sebesar 13.950 dan signifikansi ( $p$-value) sebesar $0,000(\mathrm{p}<0,05)$,

Hasil penelitian ini sejalan dengan penelitian yang dilakukan oleh Husfaudin (2016), tentang faktor yang berhubungan dengan mutu pelayanan prima di ruang rawat inap kelas 11 dan kelas 111 RSUD Petala Bumi Provinsi Riau Tahun 2016. Hasil penelitian ini menunjukkan bahwa terdapat hubungan yang kuat antara tindakan petugas 
kesehatan dengan mutu pelayanan prima di rumah sakit, peneliti menyimpulkan baik buruknya tindakan medis yang diberikan tergantung dari pelayanan yang diterima oleh pasien.

Penelitian ini juga sejalan dengan penelitian yang dilakukan oleh Ulfa, dkk (2016), tentang faktor-faktor yang berhubungan dengan pelayanan petugas pendaftaran rawat jalan terhadap pelayanan prima di RSUD Petala Bumi Provinsi Riau Tahun 2016. Hasil penelitian ini menunjukkan terdapat hubungan antara tindakan petugas pelayanan pendaftaran dengan pelayanan prima. Tindakan petugas pendaftaran rawat jalan dapat memperngaruhi pelayanan prima karena tindakan itu sendiri erat hubungannya dengan kepuasan pasien seperti, seperti mencatat keluhan pasien, memberikn informasi yang jelas kepada pasien dan selalu memberikan salam kepada pasien.

Tindakan menurut Barata (2016) adalah berbagai kegiatan nyata yang harus dilakukan dalam memberikan layanan kepada pelanggan. Daryanto dalam Ulfa, dkk (2016) pelayanan prima dengan konsep tindakan adalah bentuk konkret dari segala bentuk pelayanan sebelumnya. Pelayanan prima dengan konsel tindakan yaitu suatu cara atau rangkaian perbuatan nyata yang dilakukan untuk meyakinkan dan memberikan jaminan kepada pelanggan agar mereka tertarik dan akhirnya membeli atau menggunakan batang atau jasa yang ditawarkan.

Berdasarkan hasil penelitian dan teori yang relevan maka peneliti mendapatkan bahwa tindakan dari perawat dan bidan baik buruknya tergantung dari pelayanan yang diterima oleh pasien. Dimana dari hasil kuesioner pasien lebih banyak memilih jawaban Tidak Setuju pada "Perawat dan bidan memberikan tindakan secara cepat dan tanggap". Hal ini sangat dirasakan kurang oleh pasien dan dapat mengakibatkan kurangnya mutu pelayanan yang diterima oleh pasien, sehingga pasien perlu menunggu lama untuk mendapatkan apa yang dibutuhkan oleh pasien.

\section{Hubungan Penampilan Perawat dan} Bidan Dengan Mutu Pelayanan Prima

Hubungan penampilan perawat dan bidan dengan mutu pelayanan prima dalam rumah sakit terlihat dari hasil tabel distribusi yang menunjukkan bahwa peningkatan penampilan perawat dan bidan kearah yang lebih baik akan diikuti oleh peningkatan mutu pelayanan prima dalam pelayanan di rumah sakit. Hasil perhitungan Chi Square ditemukan ada hubungan antara penampilan 
perawat dan bidan dengan mutu pelayanan prima di rumah sakit, yaitu dengan nilai Chi Square sebesar 5.145 dan signifikansi ( $p$-value) sebesar 0,023 $(\mathrm{p}<0,05)$,

Hasil penelitian ini sejalan dengan penelitian yang dilakukan oleh Saputri (2016), tentang hubungan penampilan perawat dengan ke[uasan pasien di RS PKU Muhammadiyah Yogyakarta. Hasil penelitian ini menunjukkan bahwa terdapat hubungan yang kuat antara penampilan perawat dengan kepuasan pasien, dimana semakin baik penampilan perawat maka semakin puas yang pasien rasakan.

Hasil observasi pada faktor penampilan yang dilakukan oleh peneliti selama pengambilan data secara langsung, masih adanya perawat dan bidan yang tidak memakai id card atau tanda pengenal perawat atau bidan tersebut, selanjutnya penampilan dari ruangan rawat inap itu sendiri masih memakai fasilitas lama yang belum diperbaharui seperti : tempat tidur, closet yang sudah berkarat, serta kran air yang macet.

Penelitian ini juga sejalan dengan penelitian yang dilakukan oleh Ulfa, dkk (2016), tentang faktor-faktor yang berhubungan dengan pelayanan petugas pendaftaran rawat jalan terhadap pelayanan prima di RSUD Petala Bumi Provinsi Riau Tahun 2016. Hasil penelitian ini menunjukkan terdapat hubungan antara penampilan petugas pelayanan pendaftaran dengan pelayanan prima. Menurut peneliti, penampilan petugas pendaftaran rawat jalan yang baik mempengaruhi kualitas pelayanan kesehatan. Kepuasan pasien terhadap penampilan petugas dapat membuat pasien kembali lagi kerumah sakit dan merekomendasikan kepada orang lain.

Penampilan menurut Barata (2016) adalah penampilan seseorang baik yang bersifat fisik maupun non fisik, yang mampu merefleksikan kepercayaan diri dan kredibilitas dari pihak lain. Dalam menyelenggarakan pelayanan kepada pihak lain, baik pelayanan dalam kegiatan bisnis, kegiatan oemerintahan, dan kegiatan organisasi nirlaba, sebaiknya pihak yang melayani harus menunjukkan pribadi yang prima dalam berpenampilan. Penampilan diri (personal appearance) dengan menunjukkan pribadi yang prima, antara ain ditujukan untuk : 1) menunjukkan citra yang ingin kita tampilkan, 2) menunjukkan sikap penghargaan kita kepada orang lain, 3) menunjukkan kepantasan tampilan pada saat berinteraksi dengan orang lain. 
Berdasarkan hasil penelitian dan teori yang relevan maka peneliti mendapatkan bahwa penampilan dari perawat dan bidan baik buruknya tergantung dari penampilan yang ditampilkan dari perawat dan bidan tersebut. Sebagian besar responden menyatakan penampilan perawat dan bidan sudah baik, namun masih ada sebagian responden yang menyatakan penampilan dari perawat atau penampilan dari ruangan rawat inap tersebut tidak baik. Berdasarkan hal tersebut diharapkan perawat dan bidan agar selalu memakai id card atau tanda pengenal perawat dan bidan sesuai dengan peraturan yang ada di rumah sakit dan untuk penampilan di ruangan rawat inap sebaiknya fasilitas yang sudah lama sebaiknya diperbaharui serta fasilitas yang tidak berfungsi sebaiknya segera diperbaiki dan hendaknya rumah sakit melakukan pengecekan fasilitas minimal 1 bulan sekali.

\section{Hubungan Tanggung Jawab Perawat} dan Bidan Dengan Mutu Pelayanan Prima

Hubungan tanggung jawab perawat dan bidan dengan mutu pelayanan prima dalam rumah sakit terlihat dari hasil tabel distribusi yang menunjukkan bahwa peningkatan tanggung jawab perawat dan bidan kearah yang lebih baik akan diikuti oleh peningkatan mutu pelayanan prima dalam pelayanan di rumah sakit. Hasil perhitungan Chi Square ditemukan ada hubungan antara tanggung jawab perawat dan bidan dengan mutu pelayanan prima di rumah sakit, yaitu dengan nilai Chi Square sebesar 4.424 dan signifikansi ( $p$-value) sebesar $0,035(\mathrm{p}<0,05)$,

Hasil penelitian ini sejalan dengan penelitian yang dilakukan oleh Suwardana (2014), tentang hubungan pelaksanaan pelayanan perawat dengan kepuasan pasien rawat inap di RSUD Kabupaten Bombana Tahun 2014. Hasil penelitian ini menunjukkan bahwa terdapat hubungan antara tanggung jawab dengan kepuasan pasien, dari hasil analisis univariat menunjukkan bahwa dari 41 orang responden tentang tanggung jawab perawat di ruang rawat inap RSUD di Kabupaten Bombana sebagian besar menunjukkan kriteria kurang yakni 21 (51,2\%) orang. Penilaian tanggung jawab perawat pada penelitian ini meiputi perawat terdidik dan mampu melayani pasien, menjaga kerahasiaan pasien selama berada diruang rawat inap, dan meningkatkan kepercayaan pasien serta membantu dalam proses kebutuhan pasien. Berdasarkan indikator tersebut masih ada yang dirasakan kurang baik oleh responden yaitu perawat tidak tepat 
waktu dalam memberikan pelayanan dan belum mampu melayani pasien dengan maksimal, terbukti dengan adanya pasien yang tidak memperoleh kunjungan selama dua kali sift jaga perawat.sedangkan yang terendah yakni tanggung jawab perawat dengan kriteria baik yakni 20 (48,8\%) orang.

Penelitian ini juga sejalan dengan penelitian yang dilakukan oleh Ulfa, dkk (2016), tentang faktor-faktor yang berhubungan dengan pelayanan petugas pendaftaran rawat jalan terhadap pelayanan prima di RSUD Petala Bumi Provinsi Riau Tahun 2016. Hasil penelitian ini menunjukkan terdapat hubungan antara taanggung jawab petugas pelayanan pendaftaran dengan pelayanan prima. Tanggung jawab petugas pendaftaran rawat jalan dapat memperngaruhi pelayanan prima karena tanggung jawab merupakan kewajiban dari petugas itu sendiri untuk menjalankan tugas dengan baik.

Tanggung jawab menurut Barata (2016) adalah suatu sikap keberpihakan sebagai wujud kepedulian untuk menghindarkan atau meminimalkan kerugian kepada pelanggan, tanggung jawab dapat berupa melayani saat tidak bertugas dan tidak melakukan kesalahan dalam melayani pelanggan, maka pelanggan dapat merasakan terpenuhinya kebutuhan dan keinginan mereka sehinggan kepuasan konsumen terwujudkan.

Berdasarkan hasil penelitian dan teori yang relevan maka peneliti mendapatkan bahwa tanggung jawab perawat dan bidan baik buruknya tergantung dari pelayanan yang diterima oleh pasien. Sebagian responden menyatakan bahwa tanggung jawab perawat dan bidan buruk. Dari hasil kuesioner, responden banyak yang memilih tidak setuju pada "Perawat dan bidan melakukan pelayanan tepat waktu sesuai kebutuhan anda", "Perawat dan bidan melaksanakan tugas sesuai dengan jadwal yang diberikan" hal ini akan berakibat negatif bagi pandangan pasien terhadap profesionalisme perawat dan bidan dalam melakukan pelayanan kepada pasien. Berdasarkan hal tersebut diharapkan perawat dan bidan sebaiknya lebih bertanggung jawab dalam melakukan pelayanan dan mengingat jadwal masing-masing yang telah diberikan oleh pihak rumah sakit.

\section{KESIMPULAN}

Berdasarkan hasil penelitian faktorfaktor yang berhubungan dengan mutu pelayanan prima di ruang rawat inap kebidanan RSIA Eria Bunda Pekanbaru Tahun 2019 maka dapat disimpulkan: 
1. Terdapat hubungan antara sikap perawat dan bidan dengan mutu pelayanan prima di ruang rawat inap kebidanan RSIA Eria Bunda Pekanbaru Tahun 2019 dengan $(p$-value $=<0,05)$. Dari hasil kuesioner, responden banyak yang memilih tidak setuju pada "Ekspresi wajah perawat dan bidan dalam memberikan pelayanan baik", "Respon perawat dan bidan dalam mengatasi keluhan pasien sudah tepat" hal ini akan berakibat negatif bagi pandangan pasien terhadap profesionalisme perawat dan bidan dalam melakukan pelayanan kepada pasien.

2. Terdapat hubungan antara tindakan perawat dan bidan dengan mutu pelayanan prima di ruang rawat inap kebidanan RSIA Eria Bunda Pekanbaru Tahun 2019 dengan $(p$-value $=<0,05)$. Dimana dari hasil kuesioner pasien lebih banyak memilih jawaban Tidak Setuju pada "Perawat dan bidan memberikan tindakan secara cepat dan tanggap". Hal ini sangat dirasakan kurang oleh pasien dan dapat mengakibatkan kurangnya mutu pelayanan yang diterima oleh pasien, sehingga pasien perlu menunggu lama untuk mendapatkan apa yang dibutuhkan oleh pasien

3. Terdapat hubungan antara penampilan perawat dan bidan dengan mutu pelayanan prima di ruang rawat inap kebidanan RSIA Eria Bunda Pekanbaru Tahun 2019 dengan $(p$-value $=<0,05)$. Sebagian besar responden menyatakan penampilan perawat dan bidan sudah baik, namun masih ada sebagian responden yang menyatakan penampilan dari perawat atau penampilan dari ruangan rawat inap tersebut tidak baik.

4. Terdapat hubungan antara tanggung jawab perawat dan bidan dengan mutu pelayanan prima di ruang rawat inap kebidanan RSIA Eria Bunda Pekanbaru Tahun 2019 dengan ( $p$-value $=<0,05)$. Dari hasil kuesioner, responden banyak yang memilih tidak setuju pada "Perawat dan bidan melakukan pelayanan tepat waktu sesuai kebutuhan anda", "Perawat dan bidan melaksanakan tugas sesuai dengan jadwal yang diberikan" hal ini akan berakibat negatif bagi pandangan pasien terhadap profesionalisme perawat dan bidan dalam melakukan pelayanan kepada pasien.

5. Semua variabel penelitian berhubungan maka dapat disimpulkan bahwa mutu pelayanan prima di RSIA Eria Bunda Pekanbaru masih harus ditingkatkan lagi.

\section{SARAN}

1. Bagi pihak manajemen rumah sakit, disarankan untuk lebih meningkatkan upaya pengembangan keterampilan perawat dan bidan dalam pemberian 
asuhan keperawatan, seperti, mengadakan pelatihan service excellent atau soft skill ecara berkesinambungan sehinggan perawat mampu memberikan asuhan keperawatan secara maksimal.

2. Melakukan recovery fasilitas rumah sakit khususnya ruang rawat inap sesuai dengan standar sehingga dapat memenuhi kepuasan dan kenyamanan pasien.

3. Membuat aturan atau membuat reward dan penghargaan bagi perawat dan bidan yang berprestasi yang bertanggung jawab dalam memberikan pelayanan kepada pasien tepat waktu, dan sanksi bagi perawat dan bidan yang sering telat.

\section{DAFTAR PUSTAKA}

Alamsyah, D. (2011). Manajemen Pelayanan Kesehatan. Yogyakarta: Nuha Medika.

Asmuji. (2012). Manajemen Keperawatan. Yogyakarta: Arr-uzz Media.

Azlina. (2016). FaktorFaktor Yang Berhubungan Dengan Pelayanan Petugas Pendaftaran Rawat Jalan Terhadap Pelayanan Prima di Rumah Sakit Umum Daerah Petala Bumi Provinsi Riau Tahun 2016. Skripsi. Sekoah Tinggi Ilmu Kesehatan (STIKes) Hang Tuah Pekanbaru.
Azwar. (2010). Pengantar Administrasi

Kesehatan. Tangerang : BINARUPA

AKSARA Publisher.

Barata. (2016). Dasar-Dasar Pelayanan Prima - Jakarta : PT Elex Media Komputerindo.

Bakri. (2017). Manajemen Keperawatan Konsep Dan Aplikasi Dalam Klinik Keperawatan Professional. Yogyakarta: Pustaka Baru Press.

Budi. (2011). Manajemen Unit Kerja Rekam Medis. Yogyakarta : Quantum Sinergis Media.

Bustami. (2011). Penjaminan Mutu Pelayanan Kesehatan \& Akseptabilitasnya. Padang : Erlangga. Gunawan, Aritonang, Risnawaty. (2018). Pengukuran Kepuasan Pasien RawatInap Rumah Sakit Umum Daerah Tarakan Jakarta.Volume 1, Nomor. 1. Diakses 3 April.

Husfanudin. (2016). Faktor-faktor yang berhubungan dengan mutu pelayanan prima di ruang rawat inap kelas II dan III rumah sakit umum daerah petala bumi provinsi riau tahun 2016. Skripsi. Sekolah Tinggi Ilmu Kesehatan (STIKes) Hang Tuah Pekanbaru.

Iskandar. (2016). Pelayanan Kesehatan

Dalam Meningkatkan Kepuasan Masyarakat Di Rumah Sakit Panglima Sebaya Kabupaten Paser..Volume 4, Nomor 2. Diakses 12 April. 
Mony. (2014). Hubungan Sikap Caring

Perawat Dengan Kepuasan Pasien

Rawat InapKelas III di Rumah Sakit

PKU Muhammadiyah Yogyakarta.

Naskah Pubikasi. Sekoah Tinggi Ilmu

Kesehatan Aisyiyah Yogyakarta.

Diakses 10 juli 2019.

Nugrahaningsih. (2016). Hubungan Sikap

Perawat Dengan Kepuasan Pasien

Dalam Pelayanan Keperawatan di

Bagsal Pavilliun RSUD Salatiga.

Skripsi. Sekoah Tinggi Ilmu Kesehatan

Kusuma Husada. Surakarta. Diakses 10

Juli 2019.

Profil RSIA Eria Bunda Pekanbaru Tahun 2018

Purwoastuti. (2015). Mutu Pelayanan Kebidanan. Yogyakarta: PUSTAKABARUPRESS.

Putri, Riski Asriani (2015). Faktor- Faktor Yang Berhubungan Dengan Pelayanan Prima Pegawai Rawat Jalan Puskesmas Kecamatan Kebon Jeruk Jakarta Barat Tahun 2015. Skripsi, Universitas Islam Negeri Syarif Hidayatullah.

Rahmayanty. (2010). Manajemen Pelayanan

Prima. Yogyakarta: Graha Ilmu.

Saputri. (2016). Hubungan Penampilan Perawat Dengan Kepuasan Pasien di RS PKU Muhammadiyah Yogyakarta. Naskah Publikasi. Universitas Muhammadiyah Yogyakarta. Diakses 10 Juli 2019.
Satrianegara. (2009). Organisasi dan Manajemen Pelayanan Kesehatan serta Kebidanan. Jakarta: Salemba Medika.

Sondakh. (2013). Mutu Pelayanan Kesehatan Dan Kebidanan. Jakarta Selatan: Salemba Medika.

Sugiyono (2017). Metode Penelitian. Bandung:ALFABETA.

Surahmawati. (2015). Kualitas Pelayanan Kesehatan Di Rumah Sakit Umum Daerah Barru (Kasus Pelayanan Rawat Jalan Pasien Pengguna Asuransi Kesehatan.. Volume 7, Nomor 1. Diakses 3 April.

Suwardana (2014). Hubungan Pelaksanaan Pelaksanaan Pelayanan Perawat Dengan Kepuasan Pasien Rawat Inap di RSUD Kabupaten Bombana Tahun 2014. Diakses 10 Juli 2019.

Ulfa, Azlina. (2016). Faktor-Faktor Yang Berhubungan Dengan Pelayanan Petugas Pendaftaran Rawat Jalan Terhadap Pelayanan Prima Di Rumah Sakit Umum Daerah Petala Bumi Provinsi Riautahun 2016. Volume 4, Nomor 4. Diakses 12 April. 